\title{
Analisis Leverage Melalui Pertumbuhan Laba dan Pengaruhnya terhadap Nilai Perusahaan
}

\author{
Arna Suryani \\ Dosen Fakutas Ekonomi Universitas Batanghari \\ Correspondence email: arna_halim@yahoo.co.id
}

\begin{abstract}
This study aims to examine and analyze the effect of leverage though profit growth on firm value. Size of leverage is the rasio of debt to assets and debt to equity, and price book value is an indicator of firm value. The sample of this study was LQ45 companies listed on the Indonesia stock exchange which were selected based on certain criteria during the 2016 to 2018 observation period, and were selected as many as 34 companies so that the research sample was 102 observations. The analytical method is descriptive analysis using path analysis by testing four path structures. Normality and linearity were tested and $F$ and $t$ test the hypothesis.Based on result of the first path structure test leverage simultaneously and partially has no significant effect on profit growth. The result of the second path structure test simultaneously have a significant effect on firm value, and only partially the debt to equity ratio has a significant effect on firm value. The third path structure test that is profit growth directly has a significant effect on firm value, and the result of the fourth path structure test that is profit growth is considered capable of being a mediating link between leverage namely ratio of debt to asset (DAR) and debt to equity (DER) with price book value (firm value). These results prove that size of leverageis the ratio debt to asset and debt to equity can lead to increased profit growth, this is because profit growth is strongly influenced by management in carrying out company operations. Profit growth can also be a factor for investors or potential investors to value the company. Good news will be responded more quickly so that it will have an impact on the firm value.
\end{abstract}

Keywods: Leverage, debt to asset ratio, debt to equity ratio, profit growth, price book value

\section{Pendahuluan}

Keberhasilan suatu perusahaan dapat dilihat dari pertumbuhan laba dari tahun ketahun. Setiap perusahaan akan selalu berusaha dengan berbagai cara untuk dapat menggambarkan kinerja perusahaan yang baik. Keberhasilan suatu perusahaan dapat tergambarkan dari bagaimana kesanggupan perusahaan tersebut untuk memperoleh laba. Menurut Weston dan Copeland (2010), para pemakai laporan keuangan dapat memanfaatkan laporan laba rugi untuk memperkirakan aliran kas di masa yang akan datang, dimana tingkat profitabilitas dapat menjadi indikator dalam penilaian kemapuan perusahaan dalam menghasilkan laba dari kegiatan operasinya. Pertumbuhan laba dapat menjadi indikator keberhasilan manajemen dalam mengelola perusahaaan. Pemilik mengharapkan perusahaaan dapat berjalan dengan baik yang ditunjukkan dengan seberapa besar pertumbuhan labanya. Kemampuan untuk mendapatkan Tingkat laba yang tinggi menjadi fokus bagi perusahaan pada umumnya dibandingkan dengan hanya mendapatkan laba yang maksimal. Hal ini menunjukkan bahwa semakin tinggi kemapuan perusahaan untuk mendapatkan laba maka akan menggambarkan tingkat efisiensi yang tinggi pula. Perusahaan harus memiliki strategi untuk dapat meningkatkan laba denga memperhatikan na dengan mengetahui fator-faktor yang mempengaruhi hutang, asset, modal kerja, penjualan, dan biaya. Modal dapat dijadikan sebagai variabel oleh manajemen sebagai pertimbangkan untuk menjalankan operasi perusahaan, karena sturktur modal yang baik akan dapat menjadikan operasional perusahaan menjadi efektif dan efisien. Oleh sebab itu manajer keuangan perusahaan harus selalu memperhatikan tingkat leverge perusahaan. Dengan mempertimbangkan tingkat leverage diharapkan perusahaan akan dapat meningkatan laba.

Tingkat leverage yang baik pada suatu perusahaan dapat menjadi rujukan bagi investor atau calon investor untuk menilai suatu perusaan yang akan tergambarkan dalam harga saham suatu perusahaan. Struktur modal atau leverage merupakan perimbangan antara foreign capital dan owner's equity. Foreign capital mencakup kewajiban jangka pajang dan juga kewajiban lancar. Sedangkan owner's equity mencakup return earning dan bisa juga dengan kepemilikan saham. Investor dapat memanfaatkan laporan keuangan yang disajikan untuk mendapatkan informasi tentang perusahaan dalam menjalankan kebijakan hutangnya. Leverage perusahaan merupakan salah satu faktor fundamental dalam operasi perusahaan. Oleh sebab itu manajer harus mengkaji dengan cermat benefit dan cost dari sumber pendanaan yang akan digunakan. Tujuan utama dari sebuah perusahaan selain dari untuk memperoleh laba adalah untuk meningkatkan kemakmuran pemilik dan juga para pemegang saham melalui nilai perusahaan (Bringham dan Houston, 2010). Beberapa hal yang menjadi pertimbangan bagi investor dalam berinverstasi dengan memperhatikan struktur modal atau tingkat leverage dan pertumbuhan laba perusahaan tersebut. struktur modal atau leverage dapat dianalisis melalui rasio keuangan dengan menggunakan rasio total hutang terhadap aset dan rasio total huhang terhadap ekuitas. Rasio total hutang terhadap aset atau debt to asset ratio menggambarkan besaran modal pinjaman yang digunakan untuk investasi pada aktiva guna menghasilkan keuntungan bagi perusahaan, sedangkan 
rasio total hutang terhadap modal atau debt to equity ratio menunjukkan seberapa besar kontribusi modal dalam mendapatkan laba bersih. Semakin tinggi pertumbuhan laba menunjukkan bahwa suatu perusahaan bisa mendapatkan laba yang besar dengan memanfatkan jumlah equity yang ada secara baik (Kasmir, 2014).

Beberapa penelitian yang telah dilakukan menujukkan hasil yang berbeda Asaala (2014) menunjukkan bahwa leverage berpengaruh langsung terhadap nilai suatu perusahaan $(P B V)$. Yanuesti dan Sulasmiyati (2017) membuktikan bahwa leverage yang diukur dengan rasio hutang terhadap aset dan rasio hutang terhadap modal secara simultan berpengaruh signifikan terhadap nilai suatu perusahaan (PBV). Berliani (2018) secara simultan leverage berpengaruh terhadap nilai suatu perusahaan. Penelitian ini bertujuan untuk menguji bagaimana leverage melalui pertumbuhan laba berpengaruh terhadap nilai suatu perusahaan.

\section{Literatur \\ Leverage}

Leverage merupakan suatu permasalahan yang sangat penting bagi suatu perusahaan, hal ini disebabkan karena baik buruknya kondisi leverage akan mempengaruhi posisi financial perusahaan tersebut. leverage merupakan perimbangan jumlah utang jangka pendek yang bersifat permanen, utang jangka panjang, saham preferen, dan saham biasa (Sartono, 2010). Sedangkan menurut Fahmi (2012), leverage merupakan gambaran dari bentuk proporsi finansial perusahaan yaitu antara modal sendiri yang dimiliki yang bersumber dari utang jangka panjang dan modal sendiri yang menjadi sumber pembiayaan perusahaan. Menurut Sjahrial dan Purba (2013) rasio keuangan yang biasa digunakan di dalam memaksimalkan leverage adalah rasio total utang terhadap aset (Debt to Asset Ratio), rasio utang terhadap ekuitas (Debt to Equity Ratio), dan utang jangka panjang menurut modal (Long Term Debt to Equity Ratio).

\section{Debt To Asset Ratio}

Debt To Asset Ratio merupakan rasio utang yang digunakan untuk mengukur perbandingan antara total utang dengan total aktiva (Kasmir, 2014). Rasio Debt to Asset Ratio tinggi menunjukkan pendanaan dengan utang semakin banyak, maka semakin sulit bagi sebuah perusahaan untuk memperoleh tambahan pijaman dikarenakan ditakutkan perusahaan tidak mampu untuk menutupi utang dengan jumlah aktiva yang dimilikinya.Formulasi rasio Debt to Asset Ratio (DAR) adalah sebagi berikut.

$$
\mathrm{DAR}=\frac{\text { Total Hutang }}{\text { Total Aktiva }} \times 100 \%
$$

\section{Debt To Equity Ratio}

Debt To Equity Ratio merupakan rasio yang digunakan untuk menilai utang dengan ekuitas, yang artinya rasio ini berfungsi untuk mengetahui setiap rupiah modal sendiri yang dijadikan untuk jaminan utang. Rasio ini berguna untuk mengetahui jumlah dana yang disediakan oleh kreditor dengan pemilik perusahaan (Kasmir, 2014). Formulasi Debt To Equity Ratio (DER) adalah sebagai berikut.

DER $=\frac{\text { Total Hutang }}{\text { Total equitas }} \times 100 \%$

\section{Pertumbuhan Laba}

Pertumbuhan laba dapat menjadi salah satu indikator keberhasilan bagi badan usaha karena pertumbuhan laba dapat dijadikan ukuran efisiensi dan efektifitas suatu perusahaan. Laba merupakan salah satu tujuan utama yang ingin dicapai perusahaan (Hindiantoro, 2013:31). Adanya pertumbuhan laba yang baik dari tahun ke tahun, menggambarkan kondisi keuangan perusahaan dalam keadaan baik, sehingga hal ini akan menggambarkan kinerja keuangan perusahaan yang positif dan akan berdampak terhadap nilai perusahaan. Salah satu penilaian yang menggambarkan kondisi keuangan perusahaan tersebut adalah pertumbuhan laba (Victorson, 2012). Pertumbuhan laba dihitung dengan menggunakan rumus, yaitu:

Pertumbuhan Laba $=\frac{\text { Laba bersih } \text { tahun berjalan }- \text { laba bersih tahun sebelummya }}{\text { laba bersih } \text { tahun sebelumnya }}$

\section{Nilai Perusahaan}

Nilai perusahaan merupakan nilai jual sebuah perusahaan sebagai suatu bisnis yang sedang beroperasi (Sartono, 2010). Menurut Hemastuti (2014), nilai perusahaan merupakan persepsi investor terhadap perusahaan yang sering dikaitkan dengan harga saham. Memaksimalkan nilai perusahaan merupakan hal yang sangat penting 
bagi perusahaan, karena dengan memaksimalkan nilai perusahaan maka berarti juga memaksimalkan tujuan utama dari perusahaan itu sendiri. Menurut Harmono (2017) terdapat beberapa metode perhitungan yang digunakan dalam mengukur nilai perusahaan di antaranya adalah Price To Book Value. Price To Book Value merupakan pembagian harga pasar per lembar saham dengan nilai buku per lembar saham (Rahardjo, 2009). Rasio ini membandingkan nilai pasar investasi pada perusahaan dengan biayanya. Semakin besar rasio Price To Book Value maka semakin tinggi nilai perusahaan dinilai oleh para investor. Formulasi rasio Price To Book Value $(P B V)$ adalah sebagai berikut.

$$
\mathrm{PBV}=\frac{\text { Market } \text { Price per Share }}{\text { Book Value per Share }}
$$

\section{Kerangka Pemikiran}

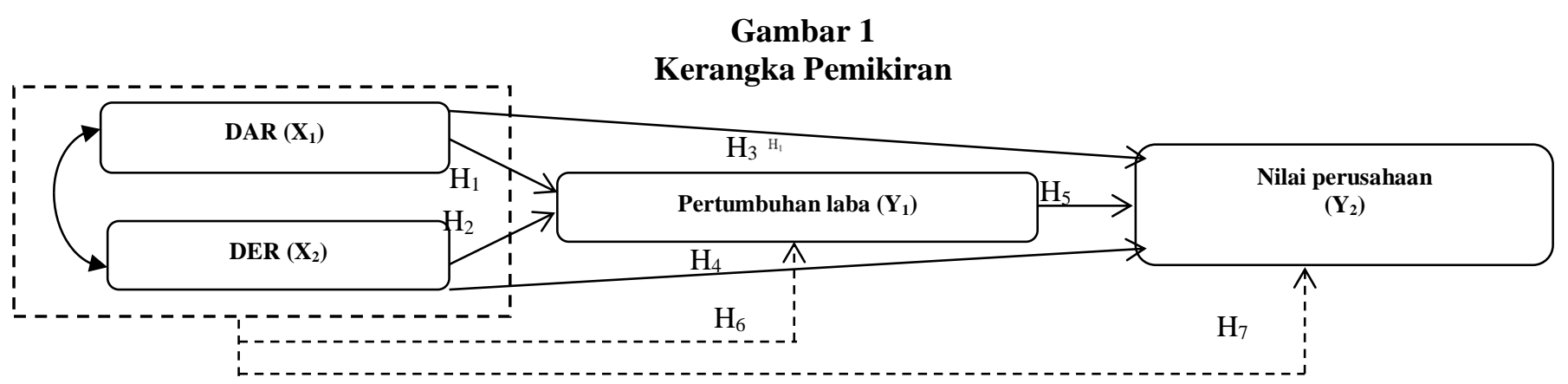

\section{Hipotesis}

H1: Debt to asset ratio dan debt to equity rasio secara simultan berpengaruh signifikan terhadap pertumbuhan laba.

$\mathrm{H}_{2}$ : Debt to asset ratio secara parsial berpengaruh signifikan terhadap pertumbuhan laba.

$\mathrm{H}_{3}$ : Debt to equity rasio secara parsial berpengaruh signifikan terhadap pertumbuhan laba.

$\mathrm{H}_{4}$ : Debt to asset ratio dan Debt to equity ratio secara simultan berpengaruh signifikan terhadap nilai perusahaan

$\mathrm{H}_{5}$ : Debt to asset ratio secara parsial berpengaruh signifikan terhadap nilai perusahaan.

$\mathrm{H}_{6}$ : Debt to equity rasio secara parsial berpengaruh signifikan terhadap nilai perusahaan.

$\mathrm{H}_{7}$ : Pertumbuhan laba berpengaruh signifikan terhadap nilai perusahaan

$\mathrm{H}_{8}$ : Debt to asset ratio dan debt to equity ratio melalui pertumbuhan laba berpengaruh signifikan terhadap nilai perusahaan.

\section{Metode}

Objek penelitian ini adalah LQ45 di Bursa Efek Indonesia periode 2016-2018. Penelitian ini menggunakan pendekatan kuantitatif dengan berdasarkan data skunder. Pemilihan sampel dilakukan menggunakan purposive sampling dengan berdasarkan beberapa kriteria tertentu. Sampel yang dipilih sebanyak 34 perusahan yang konsisten tergabung dalam Indek LQ45 selama periode pengamatan 2016 sampai 2018 sehingga terpilih sebanyak 102 pengamatan. Analisis data dilakukan dengan menggunakan path analysis untuk menguji besarnya kontribusi yang ditunjukkan oleh koefisien jalur pada setiap diagram jalur dari hubungan kausal antar variabel debt to asset ratio dan debt to equity ratio terhadap pertumbuhan laba serta dampaknya terhdap nilai perusahan. Dilakukan uji asumi klasik normalitas dan linieritas, serta dilakukan uji hipotesis $\mathrm{F}$ dan $\mathrm{t}$ dengan $\alpha 0,05$. Operasional variabel yang digunakan dapat dilihat pada tabel 1 di bawah ini.

Tabel 1

Operasional Variabel

\begin{tabular}{|c|c|c|c|}
\hline Variabel & Definisi & Rumus & Skala \\
\hline $\begin{array}{l}\text { Rasio Debt to } \\
\text { Asset }(D A R), \mathrm{X}_{1}\end{array}$ & $\begin{array}{l}\text { DAR menunjukkan berapa besarnya modal pinjaman yang } \\
\text { digunakan untuk investasi pada aktiva dapat menghasilkan } \\
\text { keuntungan. (Kasmir, 2014) }\end{array}$ & $\mathrm{DAR}=\frac{\text { Total Hutang }}{\text { Total Aktiva }}$ & Rasio \\
\hline $\begin{array}{l}\text { Rasio Debt to } \\
\text { Equty (DER), } \\
\mathrm{X}_{2}\end{array}$ & $\begin{array}{l}\text { DER adalah rasio untuk menujukkan jumlah utang dengan } \\
\text { ekuitas, yang dihitung berdasarkan perbandingan seluruh } \\
\text { kewajiban dengan seluruh ekuitas yang dimiliki perusahaan, } \\
\text { (Kasmir, 2014) }\end{array}$ & $\mathrm{DER}=\frac{\text { Total Hutang }}{\text { total equity }}$ & Rasio \\
\hline $\begin{array}{l}\text { Pertumbuhan } \\
\text { laba } \mathrm{X}_{3}\end{array}$ & $\begin{array}{l}\text { Peningkatan laba bersih dibandingkan dengan tahun } \\
\text { sebelumnya. (Harahap, 2008) }\end{array}$ & $y=\frac{Y t-Y t-1}{Y t-1} \times 100$ & Rasio \\
\hline
\end{tabular}


Price Book PBV adalah Rasio yang membandingkan nilai pasar Value (PBV) Y
$\mathrm{PBV}=\frac{\text { Market } \text { price } \text { per } \text { share }}{\text { book value per share }} \times 100 \%$

Rasio

\section{Hasil}

Tabel 2

Analisis Struktur Jalur Pertama terhadap Pertumbuhan Laba berdasarkan F test.

\begin{tabular}{llrrrrr}
\hline \multicolumn{1}{l}{ Model } & \multicolumn{1}{c}{ Sum of Squares } & Df & \multicolumn{1}{c}{ Mean Square } & F & Sig. \\
\hline 1 & Regression & 9,878 & 2 & 4,939 & 2,881 &, $060^{\mathrm{b}}$ \\
& Residual & 209,166 & 122 & 1,714 & \\
& Total & 219,043 & 124 & & \\
\hline
\end{tabular}

Sumber: data olahan

Berdasarkan tabel 2 di atas hasil pengujian menunjukkan nilai sig 0,060 maka secara bersama variabel rasio hutang terhadap aset dan rasio hutang terhadap modal tidak meeliki pengaruh yang signifikan terhadap variabel dependen (pertumbuhan laba). Dari hasil ini maka hipotesis pertama $\left(\mathrm{H}_{1}\right)$ ditolak artinya rasio total hutang terhadap aset dan rasio total hutang terhadap ekuitas tidak mempunyai pengaruh yang signifikan secara simultan pada pertumbuhan laba. Hasil ini menunjukkan bahwa perusahaan dapat melakukan strategi pendanaan dengan utang untuk mendanainya seiring dengan adanya pertumbuhan laba. Kontribusi sumbangan variabel rasio total hutang terhadap aset dan rasio total hutang terhadap ekuitas pada variabel pertumbuhan laba (PBV) yang ditunjukkan dari $\mathrm{R}^{2}$ sebesar $0.045(4,5 \%)$ yang disajikan di tabel 3 di bawah ini.

Tabel 3

Koefisien Determinasi Struktur I

\begin{tabular}{llllll}
\hline Model & $\mathrm{R}$ & $\mathrm{R}$ Square & Adjusted R Square & Std. Error of the Estimate & Durbin-Watson (DW) \\
\hline 1 &, $212^{\mathrm{a}}$ &, 045 &, 029 & 1,30938 & 1,213 \\
\hline
\end{tabular}

Sumber: data olahan

Secara parsial pengaruh variabel independen yaitu rasio total hutang terhadap aset dan rasio total hutang terhadap ekuitas pada pertumbuhan laba dapat dilihat di tabel 4 berikut.

Tabel 4

Analisis Struktur Jalur Pertama terhadap pertumbuhan laba berdasarkan $\mathbf{t}$ test

\begin{tabular}{|c|c|c|c|c|c|c|}
\hline \multirow{2}{*}{\multicolumn{2}{|c|}{ Model }} & Unstandardized Coefficients & & \multicolumn{3}{|l|}{ Standardized Coefficients } \\
\hline & & B & Std. Error & Beta & $\mathrm{t}$ & Sig. \\
\hline 1 & (Constant) & 2,766 & 1,286 & ,339 & 2,150 & ,034 \\
\hline & LN_DAR & 1,055 & 1,766 &,- 129 & ,597 &, 551 \\
\hline & LN_DER &,- 248 & 1,093 & &,- 227 &, 821 \\
\hline
\end{tabular}

Sumber: data olahan

Rasio hutang terhadap aset berpengaruh langsung terhadap pertumbuhan laba sebesar 0,115 . Besarnya pengaruh secara tidak langsung melalui rasio hutang terhadap ekuitas pada pertumbuhan laba adalah $-0,0432$ dengan total pengaruh sebesar 7,18\%. Hasil ini menggambarkan dimana rasio total hutang terhadap aset berpengaruh positif pada pertumbuhan laba yang memberikan arti jika rasio total hutang terhadap aset bertambah disebabkan meningkatnya jumlah hutang maka diindikasikan akan menyebabkan bertumbuhnya laba. Dilihat dari tingkat siginifikan yang ditunjukkan dengan nilai sig 0.551 lebih besar dari $\alpha 0,05$, maka hipotesis kedua $\left(\mathrm{H}_{2}\right)$ ditolak artinya rasio total hutang terhadap aset berpengaruh tidak signifikan pada pertumbuhan laba. Rasio hutang terhadap ekuitas berpengaruh secara langsung pada pertumbuhan laba sebesar 1,66\% dan pengaruh tidak langsung rasio total hutang terhadap ekuitas pada pertumbuhan laba melalui rasio total hutang terhadap aset sebesar $-4,32 \%$. Jadi total pengaruh rasio hutang terhadap ekuitas dengan pertumbuhan laba adalah $-2,66 \%$. Hasil ini membuktikan rasio hutang terhadap ekuitas berpengaruh tidak signifikan dengan arah pengaruh negatif pada pertumbuhan laba. Semakin besar hutang dibandingkan dengan equity akan menurunkan pertumbuhan laba karena equity dimiliki perusahaan akan digunakan untuk menutupi hutang yang ada. Dilihat dari tingkat siginifikan yang ditunjukkan dengan nilai sig 0.821 lebih besar dari $\alpha=0,05$, maka hipotesis ketiga $\left(\mathrm{H}_{3}\right)$ ditolak berarti rasio hutang terhadap ekuitas tidak berpengaruh signifikan pada pertumbuhan laba. 
Tabel 5

Rekapitulasi Struktur Jalur Pertama

\begin{tabular}{lcrrr}
\hline \multicolumn{1}{c}{ Indikator } & Langsung & \multicolumn{2}{c}{ Tidak Langsung } & Jumlah (\%) \\
\hline Rasio Debt to asset & 11,5 & $\mathbf{X}_{\mathbf{1}}$ & $\mathbf{X}_{\mathbf{2}}$ & 7,18 \\
Raiso Debt to equity & 1,66 & $-4,32$ & $-4,32$ & $-2,66$ \\
Pengaruh X dan X X $_{2}$ & & & & 4,52 \\
Pengaruh Variabel lain & & & 95,48 \\
\hline
\end{tabular}

Sumber: data olahan

Berdasarkan uji analisis, terlihat rasio total hutang terhadap aset dan rasio total hutang terhadap ekuitas, memiliki kontribusi sumbangan sebesar 4,52\% terhadap pertumbuhan laba, sedangkan sisanya sebesar 95,48\% dipengaruhi oleh variabel lainnya diluar variabel yang diteliti. Pengujian struktur jalur kedua untuk menguji pengaruh variabel rasio total hutang terhadap aset dan rasio total hutang terhadap ekuitas pada nilai perusahaan dapat dilihat pada tabel 6 berikut.

Tabel 6

Analisis uji F Struktur Jalur Kedua terhadap Nilai perusahaan

\begin{tabular}{llrrrr}
\hline & Model & Sum of Squares & Df & Mean Square & F \\
\hline 1 & Regression & 7,887 & 2 & 3,944 & 4,625 \\
& Residual & 104,025 & 122 &, 853 &, 012 \\
& Total & 111,912 & 124 & & \\
\end{tabular}

Sumber: data olahan

Tabel 6 di atas menunjukkan nilai sig 0,012 maka secara bersama variabel rasio total hutang terhadap aset dan rasio total hutang terhadap ekuitas berpengaruh signifikan terhadap nilai perusahaan. Hasil ini menunjukkan bahwa hipotesis keempat $\left(\mathrm{H}_{4}\right)$ diterima. Secara parsial pengaruh variabel rasio total hutang terhadap aset dan rasio total hutang terhadap ekuitas pada nilai perusahaan dapat dilihat pada tabel berikut:

Tabel 7

Analisis Struktur Jalur kedua terhadap Nilai perusahaan berdasarkan t test

\begin{tabular}{|c|c|c|c|c|c|c|}
\hline \multirow{2}{*}{\multicolumn{2}{|c|}{ Model }} & \multicolumn{2}{|c|}{ Unstandardized Coefficients } & \multicolumn{3}{|l|}{ Standardized Coefficients } \\
\hline & & $\mathrm{B}$ & & Beta & $\mathrm{t}$ & Sig \\
\hline \multirow[t]{3}{*}{1} & (Constant) & $-1,275$ & ,907 &,- 891 & $-1,406$ & , 162 \\
\hline & LN_DAR & $-1,985$ & 1,246 & 1,106 & $-1,594$ &, 114 \\
\hline & LN_DER & 1,525 &, 770 & & 1,979 &, 050 \\
\hline
\end{tabular}

Sumber: data olahan

Dari tabel 5 di atas rasio total utang terhadap aset memiliki pengaruh langsung sebesar 73,3\% pada nilai perusahaan dan sebesar $-97,36 \%$ pengaruh tidak langsung pada nilai perusahaan melalui rasio hutang terhadap ekuitas, sehingga total pengaruh rasio total hutang terhadap aset pada nilai perusahaan adalah $-17.97 \%$. Dilihjat dari signifikan sebesar 0.114 lebih $(>\alpha 0,05)$ maka hipotesis keempat $\left(\mathrm{H}_{4}\right)$ ditolak artinya rasio total hutang terhadap aset tidak berpengaruh signifikan pada nilai suatu perusahaan. Rasio total utang terhadap ekuitas berpengaruh langsung sebesar $122,32 \%$ dan sebesar $-97,36 \%$ pengaruh tidak langsung melalui rasio total hutang terhadap aset pada nilai perusahaan. Jadi total pengaruh rasio total hutang terhadap ekuitas pada nilai perusahaan adalah $24,96 \%$. Dilihat dari tingkat signifikansi sebesar 0,05 maka rasio total hutang terhadap ekuitas berpengaruh positif signifikan pada nilai perusahaan sehingga hipotesis kelima $\left(\mathrm{H}_{5}\right)$ diterima. Berdasarkan perhitungan koefisien jalur tersebut disajikan dalam tabel di bawah ini.

Tabel 8

Rekapitulasi Analisis Struktur Jalur Kedua

\begin{tabular}{lcrrr}
\hline \multicolumn{1}{c}{ Indikator } & Langsung & \multicolumn{2}{c}{ Tidak Langsung } & \multirow{2}{*}{ Jumlah (\%) } \\
\hline DAR $\left(X_{1}\right)$ & 79,39 & $\mathbf{X}_{\mathbf{1}}$ & $\mathbf{X}_{\mathbf{2}}$ & $-17,97$ \\
DER $\left(\mathrm{X}_{2}\right)$ & 122,32 & $-97,36$ & $-97,36$ & 24,96 \\
Pengaruh $\mathrm{X}_{1}$ dan $\mathrm{X}_{2}$ & & & 6,99 \\
Pengaruh Variabel lain & & & 93,01 \\
\hline
\end{tabular}


Uji analisis terlihat rasio total hutang terhadap aset dan rasio total hutang terhadap ekuitas, memiliki kontribusi sumbangan sebesar 6,99\% terhadap nilai perusahaan, sedangkan 93,01\% merupakan sumbangan pengaruh dari variabel lainnya yang tidak diteliti pada penelitian ini. Pengujian struktur jalur ketiga yaitu untuk mengetahui pengaruh pertumbuhan laba terhadap nilai perusahaan diperoleh hasil seperti pada tabel 9 berikut.

Tabel 9

Analisis Struktur Jalur Ketiga Terhadap Nilai Perusahaan

\begin{tabular}{|c|c|c|c|c|c|c|}
\hline \multirow{2}{*}{ Model } & \multicolumn{2}{|c|}{ Unstandardized Coefficients } & \multirow{2}{*}{\multicolumn{2}{|c|}{$\begin{array}{c}\text { Standardized Coefficients } \\
\text { Beta }\end{array}$}} & \multirow[b]{2}{*}{$\mathrm{t}$} & \multirow[b]{2}{*}{ Sig. } \\
\hline & $\mathrm{B}$ & Std. Error & & & & \\
\hline \multirow[t]{2}{*}{1} & (Constant) &,- 510 & 133 & & $-3,822$ & ,000 \\
\hline & LN_PL & ,303 & 058 & ,424 & 5,191 &, 000 \\
\hline
\end{tabular}

Sumber: data olahan

Hasil pengujian yang telah dilakukan, terlihat bahwa variabel pertumbuhan laba berpengaruh positif dan signifikan terhadap nilai perusahaan $(P B V)$ sebesar $17,98 \%$, sedangkan $82,02 \%$ merupakan pengaruh dari variabel lain selain dari variabel pertumbuhan laba. Berdasarkan tingkat signifikan sebesar 0,000 menunjukkan bahwa pertumbuhan laba mempunyai pengaruh positif dan signifikan terhadap nilai perusahaan sehinga hipotesis ketujuh $\left(\mathrm{H}_{7}\right)$ diterima. Pengujian struktur jalur keempat dilakukan untuk menguji apakah variabel pertumbuhan laba dapat menjadi variabel intervening bagi varibel rasio total hutang teradap aset dan rasio total hutang terhadap ekuitas pada nilai perusahaan. Dari hasil perhitungan di atas, terlihat bahwa pengaruh langsung rasio total hutang terhadap aset melalui pertumbuhan laba terhadap nilai perusahaan adalah sebesar negatif $12,81 \%$. Secara tidak langsung pengaruh rasio total hutang terhadap aset pada nilai perusahaan melalui rasio total hutang terhadap ekuitas adalah sebesar 1,63\%. Jadi total pengaruh yang didapatkan adalah sebesar $-11,18 \%$. Hal tersebut menggambarkan rasio total hutang terhadap aset melalui laba yang bertumbuh memberikan sumbangan pengaruh negatif pada nilai suatu perusahaan. Rasio total hutang terhadap ekuitas berpengaruh langsung melalui pertumbuhan laba pada nilai suatu perusahaan adalah $-6,05 \%$. Secara tidak langsung pengaruh rasio hutang terhadap ekuitas melalui rasio total hutang terhadap aset dan pertumbuhan laba terhadap nilai perusahaan adalah sebesar $-2,03 \%$. Jadi total pengaruh yang didapatkan adalah sebesar $-8,08 \%$. Hal ini menunjukkan bahwa rasio total hutang terhadap ekuitas melalui pertumbuhan laba memberikan sumbangan negatif terhadap nilai perusahaan. Rasio total hutang terhadap aset dan rasio total hutang terhadap ekuitas berpengaruh langsung melalui pertumbuhan laba terhadap nilai perusahaan secara bersama-sama adalah $-18,87 \%$. Sedangkan pengaruh tidak langsung diperoleh nilai sebesar $36,47 \%$. Sehingga total pengaruh yang didapatkan adalah sebesar 17,6\%. Dengan demikian, maka dapat disimpulkan bahwa secara bersama rasio total hutang terhadap aset dan rasio total hutang terhadap ekuitas melalui pertumbuhan laba memberikan sumbangan pengaruh terhadap nilai suatu perusahaan $(P B V)$ sebesar 17,6\%. Berdasarkan bukti menunjukkan peran pertumbuhan laba dalam memediasi hubungan terhadap rasio Debt To Asset ratio dan rasio Debt to Equity, dan nilai perusahaan. Hal ini menerangkan bahwa kinerja keuangan dapat dijadikan mediasi hubungan yang cukup baik antara leverage dengan nilai perusahaan pada perusahaan LQ45 periode 2016-2018 sehingga hipotesis kedelapan $\left(\mathrm{H}_{8}\right)$ diterima.

\section{Simpulan}

Perusahaan LQ45 leverage melalui rasio hutang terhdap aset dan rasio hutang terhadap equity secara bersamasama maupun parsial tidak memiliki pengaruh signifikan pada pertumbuhan laba. Secara simultan leverage yang diukur dengan rasio Debt To Asset dan Debt To Equity memiliki pengaruh signifikan terhadap Price Book Value sebagai indikator nilai suatu perusahaan. Rasio hutang terhadap aset secara parsial tidak memiliki pengaruh secara signifikan pada nilai perusahaan namun rasio hutang terhadap modal mempunyai pengaruh yang signifikan pada nilai perusahaan. Pertumbuhan laba secara langsung berpengaruh signifikan terhadap nilai perusahaan. Pertumbuhan laba dianggap mampu menjadi mediasi penghubung antara leverage dengan rasio total hutang terhadap aset dan rasio total hutang terhadap ekuitas dengan Price Book Value sebagai indikator nilai dari perusahaan. Hasil ini membuktikan bahwa leverage berdasarkan rasio total hutang terhadap aset dan rasio total hutang terhadap ekuitas dapat menyebabkan pertumbuhan laba, hal ini disebabkan karena pertumbuhan laba sangat dipengaruhi oleh seberapa besar dana yang dikelola manajemen dalam menjalankan aktivitas perusahaan. Pertumbuhan laba juga dapat menjadi rujukan bagi investor atau calon investor dalam menilai perusahaan. Berita yang baik akan cepat direspon oleh investor atau calon investor sehingga akan berdampak pada nilai perusahaan.

\section{Daftar Pustaka}

Arna, Suryani., Amilia, P. Sari., Atikah. 2019. Disclosure of social Responsibility, Profitabilitas to improve the company value.KnESocial Science Volume 1008-1016. 2019

Agus, Harjito dan Martono. 2015. Manajemen Keuangan. Yogyakarta: Ekonisia. 
Berliana, Asih. 2018. Pengaruh Profitabilitas dengan Struktur Modal sebagai Variabel Moderating Terhadap Nilai Perusahaan Pada Perusahaan Sektor Barang Konsumsi yang Terdaftar di BEI 2014-20015. Fakultas Ekonomi dan Bisnis, Bandar Lampung.

Budiyono. 2009. Statistika untuk Penelitian Edisi ke-2. Surakarta: Sebelas Maret University Press.

George, Terry dan Leslie W.Rue. 2009. Prinsip-prinsip Manajemen. Edisi Bahasa Indonesia, Bandung: PT.Bumi Aksara.

Halim, Abdul dan M.Hanafi. 2012. Analisis Laporan Keuangan. Yogyakarta: UPP STIM YKPN.

Fahmi, Irham. 2012. Analisis Laporan Keuangan. Alfabeta, Bandung Pertama, PT.Raja Grafindo Persada.

Hamidy, R. R., I Gusdi, B. Wiksuana, dan Luh Gede S. A. 2015. Pengaruh Struktur Modal Terhadap Nilai Perusahaan dengan Profitabilitas Sebagai Variabel Intervening Pada Perusahaan Properti dan Real Estate di Bursa Efek Indonesia Tahun 2008-2012, E-Jurnal Ekonomi dan Bisnis Universitas Udayana 4.10, Bali.

Harmono. 2017. Manajemen Keuangan Berbasis Balanced. Jakarta: PT.Bumi Angkasa Raya.

Hasibuan, Malayu S.P. 2011. Manajemen Sumber Daya Manusia. Jakarta: Bumi Aksara.

Hery. 2015. Analisis Laporan Keuangan. Yogyakarta: CAPS.

Kasmir. 2014. Analisis Laporan Keuangan. Jakarta: Rajawali Pers.

Makkulau, Andi Runis, Fakhry Amin, dan Abdul Hakim. 2018. Pengaruh Struktur Modal Terhadap Nilai Perusahaan dengan Profitabilitas sebagai Variabel Intervening, Journal of Economic and Business, Kendari.

Margaretha, Farah. 2014. Dasar-dasar Manajemen Keuangan. Jakarta: Dian Rakyat.

Munawir. 2010. Analisis Laporan Keuangan. Yogyakarta: Liberty Yogyakarta.

Rahardjo, Budi. 2009. Laporan Keuangan Perusahaan. Edisi Kedua, Yogyakarta: Gadjah Mada University Press.

Ridelvia, Ayu Amalia. (2017). Pengaruh Struktur Modal Terhadap Nilai Perusahaan dengan Profitabilitas Sebagai Variabel Inervening (Studi Pada Jakarta Islamic Index Periode 2011-2016, Skripsi, Widiyatama Repository, Jakarta.

Riduwan dan Engkos Achmad Kuncoro. 2017. Cara Menggunakan dan Memakai Path Analysis (Analisis Jalur), Bandung: Alfabeta.

Riyanto, Agus. 2011. Buku Ajar Metedologi Penelitian. Jakarta: EGC.

Samryn. 2011. Akuntansi Manajerial. Jakarta: Raja Grafindo Persada.

Stephen P. Robbins dan Mary Coulter. 2010. Manajemen. Edisi Kesepuluh, Jakarta: Erlangga.

Sugiyono. 2016. Metode Penelitian Bisnis. Bandung: Alfabeta.

Weston, J. Feed dan Thomas E. Copeland. 2010. Manajemen Keuangan. Jakarta: Binarupa Aksara.

Widiyanto, Joko. 2014. SPSS For Windows untuk Analisis Data Statistik dan Penelitian, Surakarta, Lap FKIP UMS. 